\title{
Indigenous entrepreneurship on customary land in the Pacific: Measuring sustainability
}

\author{
Regina Scheyvens, Glenn Banks, Litea Meo-Sewabu and Tracy Decena
}

\begin{abstract}
Customary land is commonly perceived as a barrier to economic development and indigenous entrepreneurship in Pacific Island countries. We turn this proposition on its head, arguing that customary land provides a solid foundation for indigenous entrepreneurs who wish to achieve social, cultural and environmental, as well as economic, goals for their businesses. Furthermore, we assert that appropriate tools are needed to measure the success of indigenous businesses on customary land, as conventional tools have a narrow focus on economics that fails to capture the more holistic, sustainable development goals that indigenous people hope to achieve through their businesses. The indicators we utilise relate to socio-cultural, economic and environmental sustainability. The tool's usefulness was scrutinized through pre-testing on two indigenous businesses in Fiji; this revealed that culturally oriented tools are essential if the sustainability of indigenous business is to be measured in terms that are meaningful to Pacific communities.
\end{abstract}

Keywords: Oceania, small- and medium-sized enterprises (SMEs), indigenous economic development, sustainability, sustainable development

Received 18 June 2017. Accepted 5 November 2017

\section{INTRODUCTION}

T ndigenous entrepreneurship in the Pacific has been the subject of much attention in recent decades, driven by the recognition that there are a range of noneconomic factors that play a central role in the success or otherwise of indigenous-owned businesses. Surprisingly, given the high proportion of land under customary forms of tenure across the region, there has been very little work that directly examines the significance of customary land as a social and cultural resource for indigenous business in the Pacific. In part this reflects the limited framing of business success among indigenous entrepreneurs in the Pacific, where external and donor criteria focus on financial viability. Broader criteria, taking into account social, cultural and environmental values of the community - which are encapsulated for instance, in the Fijian notion of vanua (Batibasaga, Overton, \& Horsley, 1999), are likely to produce a measure of 'success' that reflects the on-going importance of being embedded in land, and people's enduring relationships to that land. Incorporating such values into an assessment of indigenous businesses is hence more meaningful to Pacific business owners and entrepreneurs than examining financial viability alone.

School of People, Environment and Planning, Massey University, Palmerston North, New Zealand.

Corresponding author: r.a.scheyvens@massey.ac.nz 
This brief overview opens with a discussion of the economic context of development in the Pacific as an introduction to the literature on entrepreneurship in the Pacific. We then explore the linkages between customary land and entrepreneurship, highlighting the close, integrated socio-cultural relationship between people, place, land ownership and economic activity in the Pacific. The paper then moves on to methodological questions and the development and initial application of a novel tool to assess the sustainability of indigenous, customary land-based businesses in the Pacific. Our graphic tool allows for the evaluation of a more complete range of business 'sustainability success' factors that reflect, at their core, the central importance of land, and people's connections to the land, in Pacific societies. Specifically, it includes economic, socio-cultural and environmental measures. We conclude by arguing that culturally meaningful tools such as this are essential if the success and sustainability of indigenous entrepreneurship on customary land is to be measured in terms that make sense to Pacific communities.

\section{THE NEED FOR A HOLISTIC APPROACH TO ECONOMIC DEVELOPMENT AND ENTREPRENEURSHIP IN THE PACIFIC}

Conventional theories on economics have long dominated national development policies globally. These national strategies are largely guided by economic models focussed on achieving economic growth, which is still widely accepted as the mainstream notion of development and progress. In particular, the linear stage models advocated by Rostow and Harrod-Domar were long considered as the basic templates in facilitating national economic growth (Anderson \& Lee, 2010; Henderson, 2013), but they have been criticised more recently for their narrow focus on economic growth which can in fact deepen inequalities in society, their failure to capture notions of overall social well-being and for their unsustainable end goal of high mass consumption (Anderson \& Lee, 2010; Raworth, 2017: 268). New, alternative notions of economic development that embrace social, environmental, cultural and monetary elements are starting to shake up such conventional thinking and offer new ways forward for planning development; a good example is Kate Rowarth's Doughnut Economics: Seven Ways to Think Like a 21st Century Economist (Raworth, 2017).

One problem with rigid, conventional economic theories is that underlying structures and processes rooted in particular cultural contexts, such as those of Pacific Island societies, are left unrecognised and thus, undervalued. Such activities, which are characterised in community interactions, kinship and relationships, also contribute to the dynamics of an economy, but are often overlooked due to their nonmonetary nature [see Gibson-Graham (2005) and Curry \& Koczberski (2012)]. Many people of the Pacific have a strong cultural upbringing which has reinforced social relationships as the centre of their formal, informal and noncash economic activities. Meeting social obligations, gift exchange and reciprocity are some of the cultural practices deeply embedded in their economic activities (Curry, 2005; Curry \& Koczberski, 2012; Gibson, 2012); while they do not necessarily produce financial profit, they still possess significant economic value (Banks, 2007; Curry \& Koczberski, 2012; Gibson, 2012; Leokana, 2014). These cultural practices underscore the importance of the relationships and associated cultural and social capital which enables access to crucial information and resources, and helps to maintain stability and resilience of people in the Pacific (Gilberthorpe \& Sillitoe, 2009).

Small businesses add much needed diversity to the subsistence sector of many Pacific Island countries, offering a means of earning cash for medical care, education, transport and basic household goods (Cahn, 2008). However, a lot of research on such businesses in the Pacific has had a negative focus, highlighting barriers to success and poor business practices. Certainly such businesses do face unique challenges associated with the small size of domestic markets, geographical isolation and poor transport infrastructure, particularly when they are located in remote and rural areas (Hailey, 1987; 
Cahn, 2008). Vulnerability to natural disasters, which appear to be increasing in frequency and/or intensity due to climate change, adds another significant challenge. Furthermore, it can be difficult for indigenous entrepreneurs to access suitable training, technical assistance or other support, and accordingly some small businesses are characterised by under-capitalisation, low turnover and poor cash flow (Saffu, 2003). Cultural barriers to business success have also been noted. Some assert that entrepreneurialism requires individualism, which is not a valued trait in collectivist Pacific Island societies (Duncan, 2008). It is also suggested that Pacific Island entrepreneurs find it difficult to reinvest in their business because of pressure to distribute any surplus revenue to meet family or communal obligations (Finney, 1987). The expectation that free credit is provided to relatives, with no guarantee of repayment, can further damage cash flow.

While it is important to recognise these limitations faced by Pacific businesses, there are also positive cultural influences on their operations. For example, meeting communal obligations can also strengthen social capital and associated business resilience (Purcell \& Scheyvens, 2015). Similarly, businesses which give generous donations to community events generate goodwill towards their products and services. Gifting - for example, contributing to wedding or funeral expenses - can be a form of saving, safe in the knowledge that in times of need, it will be reciprocated. Thus our understanding of the potential of Pacific businesses needs to be based on an awareness of both the constraints faced by these businesses and the positive aspects of being a culturally embedded business.

Similar to the narrow focus of conventional economics, there is a Eurocentric or Ameri-centric and capitalist focus of much research on entrepreneurship, focussing on individuality and monetary success. The scholarship on entrepreneurship, however, is broadening with newer research on entrepreneurial practice acknowledging that it is 'shaped by and profoundly effects, the culture within which it operates' (Schaper, 2007: 526). Accordingly, indigenous people often develop their own styles of entrepreneurship which typically blend traditional culture and values with modern economic practices (Dana \& Anderson, 2007). Research into indigenous businesses has found that they are often characterised by community-based development goals, collective organisation and a focus on environmental sustainability (Peredo \& Anderson, 2006: 265-257). It has thus been suggested that entrepreneurship will only be sustainable if done in a manner congruent with local social norms (Hailey, 1987; Saffu, 2003). Indigenous entrepreneurs are now being encouraged to develop their businesses in ways that show respect for their culture and that build upon indigenous knowledge, heritage and the notion of community (Hindle, 2010). As Spiller et al. explains, some New Zealand Māori businesses have managed to balance traditional customs with contemporary business practices through establishing business models that explicitly recognise and acknowledge the social connectedness and cultural embeddedness of the enterprise (Spiller, Erakovic, Henare, \& Pio, 2011).

Furthermore, informal economic endeavours which are generally small-scale, unregulated and family-owned (Todaro \& Smith, 2012: 328), are important in terms of generating income and sustaining livelihoods. They are, however, not generally considered part of the conventional market system even though they provide an entry point into business for many indigenous entrepreneurs and also generate economic growth. Entrepreneurship in the informal sector enhances the productive capacity of individuals and sustains people's lives and well-being, especially when formal sector jobs are inaccessible, limited or unavailable (Duncan, 2008; Imbun, 2009). Many informal entrepreneurial activities would not exist without the existence of strong social capital.

Cultural values definitely inform the business practices and goals of indigenous enterprises in the Aotearoa New Zealand and the wider Pacific region (see e.g., Harmsworth, 2005; Lertzman \& Vredenburg, 2005; Spiller et al., 2011; Kahui \& Richards, 2014). For instance, research into 10 Solomon Islands businesses found that owners remained strongly influenced by their customary values and beliefs (Leokana, 2014). Most indigenous businesses are developed to improve family well-being and livelihood, rather than make financial profit, with economic well-being regarded as a means to fulfilling 
broader spiritual, cultural, social and environmental notions of well-being (Harmsworth, 2005). A study of 700 Pacific entrepreneurs found that in contrast to individualism and achievement, collectivist approaches were the norm for Pacific Island entrepreneurs (Saffu, 2003). Furthermore, research with entrepreneurs in Samoa found that development programmes seeking to assist indigenous entrepreneurs in the Pacific, for example, via business mentoring, will have a much greater chance of success if the mentors have a good understanding of the local cultural context, and of what Pacific entrepreneurs are striving to achieve - including their social and cultural priorities (Purcell \& Scheyvens, 2015).

\section{CUSTOMARY LAND AND INDIGENOUS ENTREPRENEURSHIP IN THE PACIFIC}

Land is conventionally understood in development discourse as a commodity and an economic asset, a notion long contested by Polanyi in his writing on 'fictitious commodities' (1944: 71). Certainly people of the Pacific view land in a more complex, holistic manner. Accordingly, words commonly translated as 'land' - such as vanua in Fiji, fonua in Tonga, enua in the Cook Islands, whenua in NZ (Batibasaga, Overton, \& Horsley, 1999) - embrace land and people and their connections. These terms are all-encompassing and include cultural, social and spiritual elements, along with people's values, beliefs, traditions and history, all interlinked with the natural and supernatural world (Batibasaga, Overton, \& Horsley, 1999; Tuwere, 2002; Nabobo-Baba, 2006). Land's ability to provide sustenance is also central to why it is valued and respected and is therefore essential to any consideration of its economic potential. Fundamentally, people of the Pacific have an intense attachment to land' (Curry, Koczberski, \& Connell, 2012: 116). This is particularly significant in the seven Pacific Island countries where customary land comprises more than $80 \%$ of the total land area (Boydell \& Holzknecht, 2003: 203).

Throughout the Pacific the values of the land are upheld by its people through cultural rituals and processes that honour the ancestors and physical and spiritual dimensions within the land. Departing from these values is believed to have negative consequences; stories abound of new developments on customary land that are understood to have failed because they did not progress in a culturally appropriate way. Accordingly, the Rotuman expression 'The land has eyes and teeth' (Hereniko, 2006), speaks to the belief that vanua is a living being that watches (with its eyes) and manifests physically through illness, accident and even death (it has teeth). This phrase was heard, for example, when the Momi Bay tourism resort in Fiji faltered in 2008, leaving half-built bungalows and metrehigh grass obstructing the $\$ 20$ million golf course (Scheyvens \& Russell, 2010: 20-21). The expression 'the land has eyes and teeth' thus points to people's profound understanding of the power of the land and its mana (Māori term for honour/authority/prestige), which demands respect from all, from foreign investors through to indigenous entrepreneurs (see e.g., Tuwere, 2002; Huffer \& Qalo, 2004). When Pacific Island entrepreneurs decide to pursue business plans based on customary land they thus tend to proceed cautiously to ensure that cultural protocols are respected.

External commentators regularly assert that customary practices around land 'constrain' economic development and impair investments in the Pacific (Prasad \& Tisdell, 1996; Hughes, 2003; Gosarevski, Hughes, \& Windybank, 2004; Lea \& Curtin, 2011). A lack of land ownership by individual freehold title is seen as hindering long-term planning, preventing banks from offering loans to indigenous entrepreneurs, and as leading to arguments over land usage (Duncan, 2008). Customary land systems are thus seen by some as 'anachronistic in modern economies' (Jayaraman, 1999: 9). Hence;

...within the island Pacific there is little sign that culture, in whatever form, is seen as a resource but much more that it is seen as a brake on hopeful structures of development. (Curry, Koczberski, \& Connell, 2012: 122)

However, a number of dissenting voices have emerged to show that culture facilitates effective businesses on customary land (Fingleton, 2004; Huffer \& Qalo, 2004; Bourke, 2005; Iati, 2009; Allen, 
2012; Curry \& Koczberski, 2012; McCormack \& Barclay, 2013). There is now growing recognition even from the World Banks and the Food and Agriculture Organization of the United Nations - that customary tenure can be more flexible and adaptable than previously assumed, and valuable for achieving a variety of development purposes (Fingleton, 2004; National Land Development Taskforce, 2007; Ward \& Kingdon, 2007; AusAid, 2008). Culturally embedded alternative economic development approaches have strong implications for development policy and donor communities who are keen to support strategies that 'enable commercial development on customary land while at the same time maintaining and protecting customary group ownership' (Allen, 2012: 300).

Research has shown that long-term relationships between partners are a key element of good Pacific business models (Gilbert, Rickards-Rees, Spicer, \& Coates, 2013). The relationships that adhere around and facilitate business engagements with customary land - be they with donors, government, churches, Non-Government Organisations (NGOs) or other private sector entities - and how they embody and express local cultural values, are crucial in the success of businesses of people of the Pacific. Ties to the land shape the nature of, and power within, the different relationships through which such economic engagements are developed and flourish. Research on economic enterprises in the agricultural sector in the Pacific has found, for example, strong collaborative relationships between the enterprise and its producers was of prime importance in achieving good development outcomes for communities (Coates, Clark, \& Skeates, 2010).

People of the Pacific have been involved in a diverse range of businesses based around customary land that are associated with agriculture, tourism, fisheries and forestry (Ward \& Kingdon, 2007; Lea, 2009; Gibson, 2012; Garnevska, Joseph, \& Kingi, 2014). For many emerging entrepreneurs in the Pacific, customary land is their greatest asset upon which they can build a business, whether they are planning an ecotourism enterprise in the rainforest, a plantation producing coffee or adding value through making cosmetics out of virgin coconut oil produced on customary land. However, that land is never perceived only as an economic asset to them; if they use it for a business, they must do so in ways which respectfully contribute to the wider society. Importantly, it is entrepreneurs, small businesses and sometimes NGOs, rather than foreign direct investment, that play a crucial role in driving much of this economic development (Coates, Clark, \& Skeates, 2010). Further, successful productive enterprises in the Pacific are often organised around individuals, families and kin networks, with flow-on benefits to communities through gift-giving, reciprocity and financial support for communal activities (Cahn, 2008; Curry \& Koczberski, 2012). Family systems can be used, particularly by women, to encourage and enhance business success; beach fale tourism in Samoa provides a good example (Scheyvens, 2006). In addition, farmers in Fiji have been able to form successful collective enterprises by developing management groups that separate farm assets and income from village social obligations, whilst still being seen to contribute to the communal capital of the village (Duncan, 2008).

\section{MEASURING SUCCESS OF INDIGENOUS BUSINESSES}

The discussion thus far has demonstrated that culture informs Pacific Island entrepreneurs' business goals and their business practices on customary land. When seeking to measure success or effectiveness of indigenous businesses on customary land, it is therefore vital to use tools which accommodate the unique approaches and socio-cultural goals of these businesses; using only financial measures of success fails to capture the value of these businesses. Entrepreneurial success in the Pacific, as shown above, is likely to be associated with the ability to meet traditional obligations and to maintain close ties with extended family, wantoks and clans (including utilising their support).

We have thus developed a tool (see Table 1 and Figure 1) which identifies factors that contribute to the sustainability of indigenous businesses operating on customary land in the Pacific. This tool is particularly inspired by Paul James' model of 'circles of sustainability', which he applied to urban 
Indigenous entrepreneurship on customary land in the Pacific

Table 1. Indicators of sustainability in PaCific Island businesses on customary land ${ }^{a}$

Subcategories Indicators

\title{
Economic indicators
}

1. Establishment

2. Ownership and management

3. Employment

4. Capacity development

5. Profit

6. Multiplier effects

\author{
Years of operation \\ Percentage of indigenous owners and managers \\ Extent to which decisions are made by indigenous owners \\ Local jobs created \\ Salary and wages \\ Level of staff retention \\ Training received by the landowners and the employees \\ Self-reported business performance (very good, okay or weak) \\ Linkages with local enterprises which benefit from the business
}

Socio-cultural indicators

\section{Collective social benefits}

8. Relationships

9. Well-being and self-determination

10. Cultural embeddedness
Commitment of the business to contribute to social or cultural groups, events, etc.

Relationships are based on the values of inclusiveness, respect and reciprocity

The business contributes to local perceptions that indigenous development is possible

The business is true to the values of the vanua/enua/whenua and wellbeing of the local community is a key consideration

Business operations and practices respect and enhance local customs

Cultural protocols are upheld

Environmental indicators
11. Sustainable use of natural resources

12. Local sourcing of materials

13. Environmental policy

14. Stewardship
Land and other natural resources are used but not degraded Good waste management practices (reduce, reuse, recycle)

Utilising local materials minimises the carbon footprint

The business has and implements a well-structured environmental policy across its operations and/or abides with government regulations on the environment

The business owners respect their role as guardians of the land, protecting it for future generations

Note.

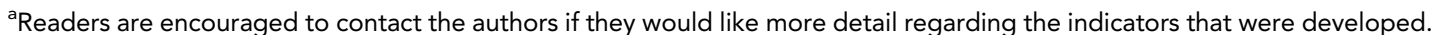

settings (James, 2015). His circle has four domains (economics, ecology, politics and culture) whereas ours has three (socio-cultural, economic, environmental). Fundamentally, both James' and our model operate on the premise that it is useful to provide a visual representation of the extent to which various dimensions of sustainability have been achieved in a particular context.

In developing indicators to assess the sustainability of indigenous businesses operating on customary land in the Pacific, we drew from a wide body of literature as well as the collective expertise of the authors, one of whom is Fijian (Meo-Sewabu) and three of whom have many years of experience doing research in and with people from the Pacific (Meo-Sewabu, Scheyvens and Banks). This led us to develop the subcategories and indicators shown in Table 1, which provides a simplified version of the table we are utilising in our research to identify how various indigenous businesses on customary land fare in terms of three aspects of sustainability; we acknowledge, however, that in some cases there is overlap for example with socio-cultural and economic indicators. Note that the indicators in this table might also be modified 
post fieldwork in response to what we find from applying the tool in our pilot studies. As it will become clear, culture is embedded within each measure of the economic, environmental and socio-cultural spheres of business operations.

\section{PROCESS FOR APPLYING THESE INDICATORS}

Conducting this research in the Pacific meant that it was appropriate to utilise a novel combination of the Vanua Research Framework and the Tali magimagi research framework. The latter weaves together culturally appropriate and ethical research practices (Meo-Sewabu, 2015), while Vanua research is grounded in indigenous values which '...supports and affirms existing protocols of relationships, ceremony, and knowledge acquisition. It ensures that the research benefits the vanua...' (NaboboBaba, 2006: 25). This meant that a number of cultural protocols that had to be adhered to when entering the research field. For Fiji, this included making initial contacts through members of our advisory group, addressing the participants in the Fijian language, and discussing commonalities and points of connection to the vanua before discussing the purpose of the actual research. Later testing of our business sustainability tool in Samoa and Papua New Guinea will be guided by the same principles.

An example of how we applied the indicators from our tool in a culturally appropriate way during pretesting was in relation to our questions. Initially there was a set of pre-prepared questions that were to be asked in sequence but in following the Vanua research framework it was culturally appropriate to use talanoa (story-telling or conversation), allowing the conversations to flow rather than asking people to answer questions verbatim (Vaioleti, 2006). Talanoa enables an openness to what is being discussed and occurs more naturally allowing the respondent to agree or disagree, share their stories, as well as openly discuss other issues relating to the research (Otsuka, 2005; Nabobo-Baba, 2006; Vaioleti, 2006). Thus rather than rushing people, there was time for intricate details of their stories to be shared, which seemed to allow the participants to speak more freely about their business. In addition, the questions were changed in terms of sequence of what was being asked. For example, it seemed more culturally appropriate to begin by asking participants about the history of their business - how and when it had started. Questions were then amended accordingly with probing questions added to ensure the talanoa flowed. Some financial questions proved to be difficult for participants. Asking about profit was a sensitive matter and therefore it was left up to the discretion of the respondent whether they wished to share such information. In future, we will just ask if they are happy with the profits or not. Employment was a touchy subject for one respondent as the turnover rate was high as a result of workers becoming qualified and preferring to work elsewhere. In such cases, our research team will need to reflect on whether there are other ways in which we can investigate issues where it is not appropriate to ask for a direct answer from the respondent being interviewed. Interestingly, questions on environmental criteria were also somewhat awkward to ask during the pretesting as it felt like the researcher was interrogating how the business managed waste. These questions were amended and it is suggested that it might be more appropriate to explore environmental aspects of the business via talanoa when doing a site visit. On the other hand, questions included in the socio-cultural criteria were easy to discuss in talanoa form as this naturally flowed on from how businesses were contributing to the community as well as what makes them successful.

On reflection, the process we used during pretesting of the business sustainability tool was largely appropriate, especially as we had flexibility to change our approach in response to the environment. Adhering to the Vanua Research Framework showed our respect for our research participants. For example, at the end of the talanoa the interviewees were given a koha (Māori term for gift or offering) to thank them for their time; they were also told that they might be consulted in future if we were considering their business for the more detailed case studies that will be carried out in phase 2 of our research project. One thing we might do during the remainder of the research project is to work with a 'cultural discernment group' when doing field research on indigenous businesses. A cultural 
discernment group includes people with intimate cultural knowledge who can guide researchers to ensure the research occurs appropriately within cultural boundaries (Meo-Sewabu, 2014). This could include advising on appropriate ways of asking questions, or on how to reframe questions so that they are not too confrontational.

\section{RESULTS OF THE PRETESTING}

Meo-Sewabu piloted the tool in two indigenous businesses in Fiji in February 2017. A representation of the resultant circle of sustainability for one of these businesses is shown in Figure 1.

Figure 1 provides a snapshot of the information we collected on one of two Fijian businesses run by indigenous entrepreneurs, which were part of our pretesting. The circles of sustainability tool thus provides a quick visual means of analysing the extent to which different criteria associated with

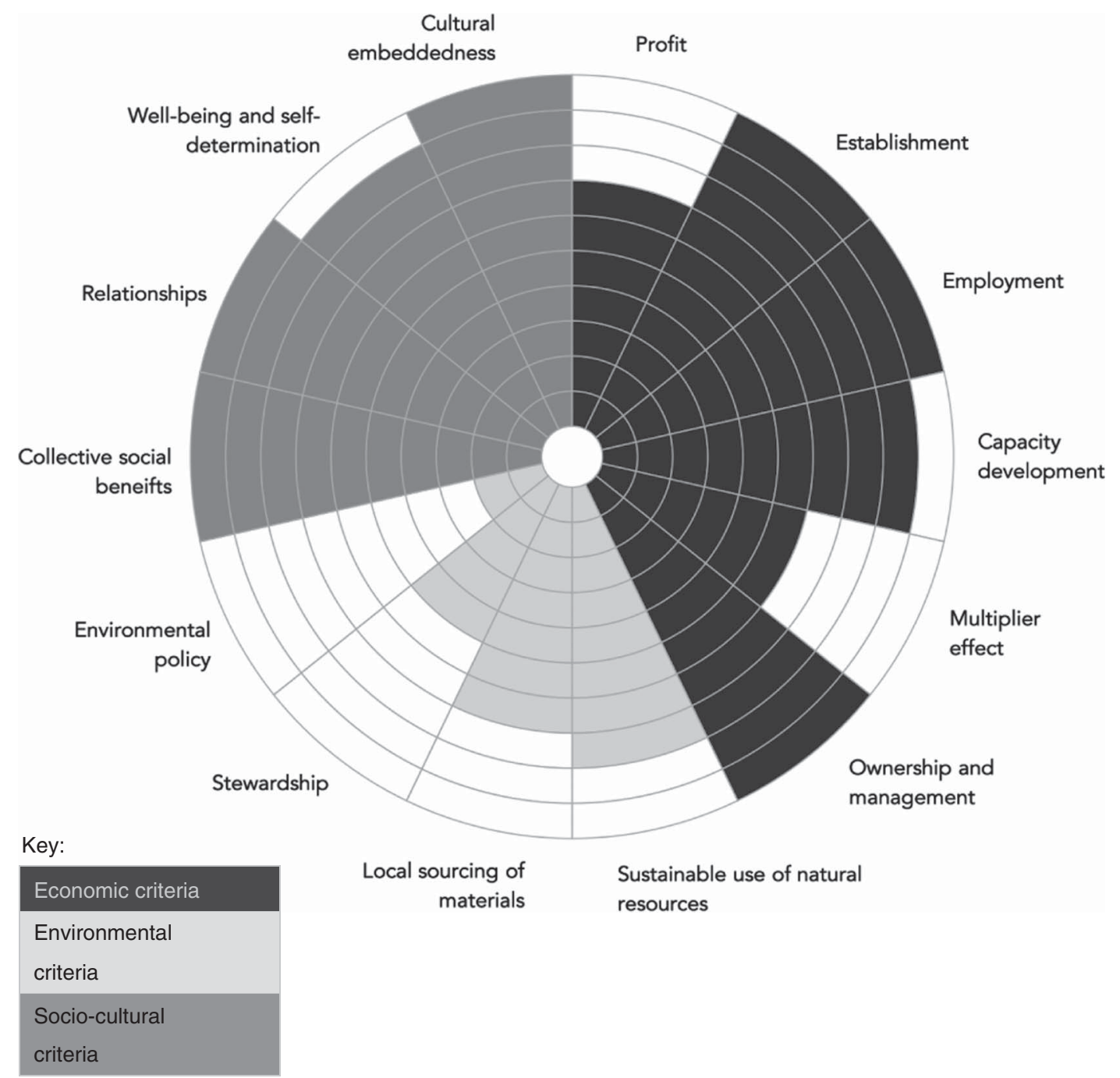

FigURE 1. InDIGENOUS BUSINESS X: SOCIO-CULTURAL, ECONOMIC AND ENVIRONMENTAL SUSTAINABILITY 
sustainable practice of indigenous business are addressed by the particular business. In this case, Indigenous Business $\mathrm{X}$ is very strong in terms of its contributions to socio-cultural well-being of the community in which it is located. It could also be regarded as scoring very well on economic criteria overall: even though the profits were not seen to be very strong, and the multiplier effects were not extensive, it scored well in this category because the business was indigenous-owned and managed (as opposed to many businesses on customary land in Fiji which, via lease arrangements, are owned and operated by foreigners), it had been established and running effectively for a relatively long period of time, and it employed people solely from the local community. This business did not rate so strongly on environmental criteria; a manager admitted they had paid little attention to date to environmental aspects of the business. In the face of the socio-cultural, economic and cultural aspects of success, the environmental aspects are not currently as significant for this business. This does not however, mean that the environment should not figure in calculations of indigenous business success and sustainability, because as we have argued above in the discussion of vanua, the 'environment' is closely tied to other aspects of the land and society in the Pacific.

\section{CONCLUSION}

This article has shown that land is a key social, cultural and economic resource for indigenous business in the Pacific, and that there is particular promise in considering customary land as a basis for indigenous entrepreneurship and business success. Land, and the complex web of social, cultural, political and economic relationships that are woven through it in Pacific societies, is both integral to the identities of diverse groups of people in the Pacific and a central resource for their development. When examining the economic potential of that land, therefore, it would be remiss not to acknowledge the socio-cultural and environmental significance of the land as well.

The significance of these other elements is clear in the way in which Pacific entrepreneurs run their businesses. We have discussed how, rather than focussing on individual gain and maximising shortterm financial profits, many Pacific businesses take a more collective approach to their endeavours, balancing customs with contemporary business practices. While doing so can lead to greater risks for the business in some ways, it can strengthen it in others. Thus when a business honours communal obligations this can strengthen social capital, generate goodwill towards their products and services, and develop business resilience based on the resulting reciprocal obligations. Overall, this can contribute to longevity and sustainability of the business. Thus our understanding of the potential of Pacific businesses needs to be based on an awareness of both the constraints faced by these businesses and the positive aspects of being a socially-connected and culturally embedded business.

As noted at the outset, despite the high proportion of land under customary forms of tenure across the region, there has been very little work that directly examines the significance of customary land as a social and cultural resource for indigenous business in the Pacific. This reflects the limited framing of business success among indigenous entrepreneurs in the Pacific, where external and donor criteria focus on financial viability. We have thus asserted that when measuring the sustainability of indigenous businesses it is very important to consider socio-cultural, economic and environmental factors, something that standard evaluations of indigenous entrepreneurial business success have failed to do. The tool for measuring sustainability of businesses on customary land in the Pacific that we developed (Table 1 and Figure 1) is thus based on a broad range of criteria. Our argument is that culturally meaningful tools such as this are essential if the sustainability of indigenous businesses is to be measured in terms that make sense to Pacific communities. We will continue to test this tool in our research, and would welcome its application by other researchers, particularly those interested in examining indigenous entrepreneurship and businesses on customary land. 


\section{References}

Allen, M. G. (2012). Informal formalisation in a hybrid property space: The case of smallholder oil palm production in Solomon Islands. Asia Pacific Viewpoint, 53(3), 300-313. https://doi.org/10.1111/j.14678373.2012.01489.x

Anderson, T., \& Lee, G. (2010). Understanding Melanesian customary land. In T. Anderson and G. Lee (Eds.), In Defence of Melanesian Customary law (pp. 2-4). Erskineville, NSW: Aidwatch.

AusAid (2008). Making land work. Volume Two. Case studies on customary land and development in the Pacific. Canberra: Australian Agency for International Development. Retrieved from http://dfat.gov.au/about-us/publications/ Documents/MLW_VolumeTwo_Bookmarked.pdf

Banks, G. (2007). 'Money Rain': Indigenous engagement with business models in Papua New Guinea. Development Bulletin, 72, 36-39.

Batibasaga, K., Overton, J., \& Horsley, P. (1999). Vanua: Land people and culture in Fiji. In J. Overton \& R. Scheyvens (Eds.), Strategies for sustainable development: Experiences from the Pacific. London/New York: Zed Books.

Bourke, R. M. (2005). Customary land tenure and agricultural success: The Mekeo case. In J. Fingleton (Ed.), Privatising land in the Pacific: A defence of customary tenures (pp. 16-22). Canberra: The Australia Institute.

Boydell, S., \& Holzknecht, H. (2003). Land-caught in the conflict between custom and commercialism. Land Use Policy, 20(3), 203.

Cahn, M. (2008). Indigenous entrepreneurship, culture and micro-enterprise in the Pacific Islands: Case studies from Samoa. Entrepreneurship \& Regional Development, 20(1), 1-18. https://doi.org/10.1080/ 08985620701552413

Coates, B., Clark, J., \& Skeates, R. (2010). Learning from experience. Sustainable economic development in the Pacific. Retrieved from http://www.oxfam.org.nz/sites/default/files/reports/learning-from-experience7.pdf

Curry, G. N. (2005). Doing 'business' in Papua New Guinea: The social embeddedness of small business enterprises. Journal of Small Business and Entrepreneurship, 18(2), 231.

Curry, G. N., \& Koczberski, G. (2012). Relational economies, social embeddedness and valuing labour in Agrarian change: An example from the developing world. Geographical Research, 50(4), 377-392.

Curry, G. N., Koczberski, G., \& Connell, J. (2012). Introduction: Enacting modernity in the Pacific? Australian Geographer, 43(2), 115-125. https://doi.org/10.1080/00049182.2012.682291

Dana, L., \& Anderson, R. (Eds.) (2007). International handbook of research on Indigenous entrepreneurship. London: Edward Elgar.

Duncan, R. (2008). Cultural and economic tensions in Pacific Islands' futures. International Journal of Social Economics, 35(12), 919-929. http://www.emeraldinsight.com/journals.htm?issn $=0306-8293$

Fingleton, J. (2004). Is Papua New Guinea viable without customary groups? comment. Pacific Economic Bulletin, 19(2), 96-103. http://peb.anu.edu.au/issues/current_issue.php

Finney, B. (1987). Business development in the highlands of Papua New Guinea. Research Report Series No. 6. Honolulu: Pacific Islands Development Program, East-West Center.

Garnevska, E., Joseph, H., \& Kingi, T. (2014). Development and challenges of cocoa cooperatives in Papua New Guinea: Case of Manus province. Asia Pacific Business Review, 20(3), 419-438. https://doi.org/10.1080/ 13602381.2014.931046

Gibson, D. (2012). The cultural challenges faced by indigenous owned SMTEs in Fiji. The Journal of Pacific Studies, $32(2), 102-126$.

Gibson-Graham, J. K. (2005). Surplus possibilities: Postdevelopment and community economies. Singapore Journal of Tropical Geography, 26(1), 4-26. https://doi.org/10.1111/j.0129-7619.2005.00198.x

Gilbert, M., Rickards-Rees, C., Spicer, N., \& Coates, B. (2013). Sustainable development in the Pacific and the role of the New Zealand Private Sector. Retrieved from Auckland http://www.oxfam.org.nz/sites/default/files/reports/ Sustainable Development Pacific report - low res - FINAL.pdf

Gilberthorpe, E., \& Sillitoe, P. (2009). A failure of social capital: Lessons from Papua New Guinea in the current economic crisis. Anthropology News, 50(7), 15-16. https://doi.org/10.1111/j.1556-3502.2009.50715.x

Gosarevski, S., Hughes, H., \& Windybank, S. (2004). Is Papua New Guinea viable with customary land ownership? Comment. Pacific Economic Bulletin, 19(3), 133-136. http://peb.anu.edu.au/issues/current_issue.php

Hailey, J. M. (1987). Entrepreneurs and indigenous business in the Pacific. Honolulu, Hawaii: Pacific Islands Development Program. 
Harmsworth, G. (2005). Report on the incorporation of traditional values/tikanga into contemporary Maori business organisation and process (Landcare Research Report LC/0405/058). Retrieved from Palmerston North http://www. landcareresearch.co.nz/publications/researchpubs/Harmsworth_report_trad_values_tikanga.pdf

Henderson, G. (2013). Value in Marx. Minneapolis: University of Minnesota Press.

Hereniko, V. (Writer). (2006). Pear ta ma 'on maf. = The land has eyes (Video recording). Northcote, VIC: Umbrella Entertainment.

Hindle, K. (2010). How community context affects entrepreneurial process: A diagnostic framework. Entrepreneurship \& Regional Development, 22(7/8), 599-647. https://doi.org/10.1080/08985626.2010.522057

Huffer, E., \& Qalo, R. (2004). Have we been thinking upside-down? The contemporary emergence of Pacific theoretical thought. The Contemporary Pacific, 16, 87-116.

Hughes, H. (2003). Aid has failed the Pacific. Sydney: Centre for Independent Studies.

Iati, I. (2009). Reconsidering land reform in the Pacific (Research paper). Wellington: Council for International Development.

Imbun, B. Y. (2009). Is the potential of labour's contribution to development acknowledged in the Pacific island countries? Pacific Economic Bulletin, 24(1), 96-112.

James, P. (2015). Urban sustainability in theory and practice: Circles of sustainability. London: Earthscan from Routledge.

Jayaraman, T. K. (1999). Private sector development and competition in the South Pacific: A case study of Vanuatu. South Pacific Study, 19(1-2), 32-49.

Kahui, V., \& Richards, A. C. (2014). Lessons from resource management by Indigenous Maori in New Zealand: Governing the ecosystems as a commons. Ecological Economics, 102, 1-7. http://www.sciencedirect.com/science/ journal/09218009

Lea, D. (2009). New initiatives in the development of customary land: Group versus individual interests. Pacific Economic Bulletin, 24(1), 49-64.

Lea, D., \& Curtin, T. (2011). Land law and economic development in Papua New Guinea. Newcastle upon Tyne: Cambridge Scholars.

Leokana, T. (2014). Understanding the experiences of small business developments: A case study of local business owners in Choiseul Province, Solomon Islands: Master of Management at Massey University, Palmerston North.

Lertzman, D. A., \& Vredenburg, H. (2005). Indigenous peoples, resource extraction and sustainable development: An ethical approach. Journal of Business Ethics, 56(3), 239-254.

McCormack, F., \& Barclay, K. (2013). Insights on capitalism from Oceania. In F. McCormack \& K. Barclay (Eds.), Engaging with capitalism: Cases from Oceania (pp. 1-27). Bingley, UK: Emerald Group Publishing Limited.

Meo-Sewabu, L. (2014). Cultural discernment as an ethics framework: An Indigenous Fijian approach. Asia Pacific Viewpoint, 55(3), 345-354.

Meo-Sewabu, L. (2015). 'Tu ga na inima ka luvu na waqa': The cultural constructs of health and wellbeing amongst Marama iTaukei in a Fijian village in Lau and in a transnational Fijian community in Whanganui, Aotearoa. PhD, Massey University, Palmerston North.

Nabobo-Baba, U. (2006). Knowing and learning: An indigenous Fijian approach. Suva: Institute of Pacific Studies, University of the South Pacific.

National Land Development Taskforce (2007). The national land development national taskforce report. Land administration, land dispute settlement and customary land development. Monograph 39. Boroko, Papua New Guinea: National Research Institute.

Otsuka, S. (2005). Talanoa research: Culturally appropriate research design in Fiji. Paper presented at the Proceedings of the Australian Association for Research in Education (AARE) 2005 International Education Research Conference. Creative Dissent-Constructive Solutions, Melbourne.

Peredo, A., \& Anderson, R. (2006). Indigenous entrepreneurship research: Themes and variations. In C. Galbraith \& C. H. Stiles (Eds.), Developmental entrepreneurship: Adversity, risk, and isolation (Vol. 5, pp. 253-273). Amsterdam: Emerald Group Publishing Limited.

Polanyi, K. (1944). The great transformation. New York: Farrar \& Rinehart.

Prasad, B. C., \& Tisdell, C. (1996). Getting property rights 'Right': Land tenure in Fiji. Pacific Economic Bulletin, 11(1), 31-46. http://peb.anu.edu.au/issues/current_issue.php

Purcell, G., \& Scheyvens, R. (2015). International business mentoring and development: Importance of local context and culture. International Journal of Training and Development, 19, 211-222. 
Raworth, K. (2017). Doughnut economics: Seven ways to think like a 21st century economist. London: Random House. Saffu, K. (2003). The role and impact of culture on South Pacific island entrepreneurs. International Journal of Entrepreneurial Behavior \& Research, 9(2), 55-73. https://doi.org/10.1108/13552550310461045

Schaper, M. (2007). Aboriginal and Torres Strait Island entrepreneurship in Australia: Looking forward, looking back. In L. Dana \& R. Anderson (Eds.), International handbook of research on Indigenous entrepreneurship. London: Edward Elgar.

Scheyvens, R. (2006). Sun, sand, and beach fale: Benefiting from backpackers - The Samoan way. Tourism Recreation Research, 31(3), 75.

Scheyvens, R., \& Russell, M. (2010). Sharing the Riches of Tourism, Summary Report - Fiji. Palmerston North: Massey University.

Spiller, C., Erakovic, L., Henare, M., \& Pio, E. (2011). Relational well-being and wealth: Māori businesses and an ethic of care. Journal of Business Ethics, 98(1), 153-169. https://doi.org/10.1007/s10551-010-0540-z

Todaro, M. P. and Smith, S. C. (2012). Economic Development. Boston: Addison-Wesley.

Tuwere, I. S. (2002). Vanua: Towards a Fijian theology of place. Suva, Fiji/Auckland, New Zealand: Institute of Pacific Studies, University of the South Pacific/College of St. John the Evangelist.

Vaioleti, T. M. (2006). Talanoa research methodology: A developing position on pacific research. Waikato Journal of Education, 12, 21-34.

Ward, G., \& Kingdon, E. (2007). Land, custom and practice in the South Pacific. Cambridge: Cambridge Press. 